\title{
Identifying vegetarians and their food consumption according to self-identification and operationalized definition in Finland
}

\author{
Markus Vinnari ${ }^{1, *}$, Jukka Montonen ${ }^{2}$, Tommi Härkänen ${ }^{2}$ and Satu Männistö ${ }^{3}$ \\ ${ }^{1}$ Turku School of Economics, Finland Futures Research Centre, Hämeenkatu 7 D, Fl-33100 Tampere, Finland: \\ ${ }^{2}$ National Public Health Institute, Department of Health and Functional Capacity, Helsinki, Finland: ${ }^{3}$ National \\ Public Health Institute, Department of Health Promotion and Chronic Diseases Prevention, Helsinki, Finland
}

Submitted 2 July 2007: Accepted 6 March 2008: First published online 8 May 2008

\begin{abstract}
Objectives: To determine the prevalence and sociodemographic factors related to vegetarians according to different definitions in Finland and to compare the consumption of selected foodstuffs and nutritional intakes among vegetarians and omnivores.

Design: Information about subjects' identification as vegetarians in a survey was used as a basis for self-defined vegetarianism. Foodstuffs consumed and their frequencies of consumption were obtained, and the reported consumption frequencies of meat, fish, milk and eggs or food portions containing these foodstuffs were used as a basis for an operationalized definition of different types of vegetarianism. Reported consumption was used to estimate foodstuff and nutritional intakes.

Setting: Three large nationwide surveys in Finland.

Subjects: In total, 24393 participants aged between 18 and 79 years were included. Results: The proportion of self-identified vegetarians was $3 \cdot 3 \%$ of the total population in Finland. According to responses to questions on consumption frequency, $1 \cdot 4 \%$ of the population were pesco-lacto-ovo-vegetarians, $0.43 \%$ were vegans, lacto-vegetarians or lacto-ovo-vegetarians, and $0 \cdot 18 \%$ were vegans or lacto-vegetarians. Eighty per cent of the self-identified vegetarians did not follow a vegetarian diet according to the operationalized definition, but they consumed fewer meat products $(P<0 \cdot 01)$.

Conclusion: Some self-defined vegetarians do consume red meat, poultry or fish, but they follow a healthier diet than self-defined omnivores. In the same sample self-identification indicated more than double the incidence of vegetarianism than the operationalized definition. Therefore self-identification is not a good method for observing the prevalence of vegetarianism.
\end{abstract}

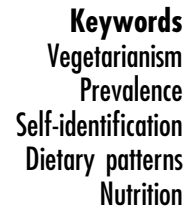

Keywords etarianism If-identification Detary patterns Nutrition
There is wide variation in the definition of a vegetarian $\operatorname{diet}^{(1-3)}$. Some definitions consider the exclusion of certain foodstuffs as the defining principle of vegetarianism. In the scientific literature, the term pesco-lacto-ovovegetarian (PLOV) signifies a person who consumes fish, milk, eggs and plant-based substances, but no meat or poultry. Sometimes the term vegetarian is understood to mean a person consuming plant-based substances, milk and eggs, i.e. lacto-ovo-vegetarian (LOV), but no fish, poultry or meat. A person who consumes only plantbased substances is considered a vegan. In other definitions consumption frequency is the defining factor. Some people use the term semi-vegetarian (SV) to describe a person who consumes meat products very rarely ${ }^{(4)}$, while others define vegetarianism as a diet according to which meat, poultry or fish is eaten less than once a week ${ }^{(5,6)}$.
The numbers of vegetarians, and especially of the different types, in Western countries are not known because estimates have been based on rather small samples or there has been wide variation in sampling methods ${ }^{(7-9)}$. According to the results of previous studies in the European Union, the prevalence of self-identified vegetarians is about 3 to $5 \%$ of the total population ${ }^{(10)}$. In Great Britain, according to different surveys ${ }^{(11,12)}$, it is between 5 and $7 \%$. Self-identification surveys in the USA have given high percentage rates of vegetarians $(7 \%)$ in the total population ${ }^{(13)}$, but some prevalence studies have put the number as low as $2 \%{ }^{(5)}$. In Finland only some rough estimates have been made, and the assumed proportion is about $2-3 \%$ of the total population ${ }^{(14-16)}$. A Finnish survey of 12-18-year-olds estimated the incidence of selfidentified vegetarianism as $9.9 \%$ for girls and $1.7 \%$ for 
boys in $2001^{(17)}$. What seems likely is that its prevalence has increased substantially during the last few decades in the Western world ${ }^{(5,6)}$. It has been reported that this growth is likely to continue in the future because of technological, social and economic developments ${ }^{(18)}$.

Vegetarianism has raised a lot of interest in the medical context because of its possible effects in terms of decreasing risks from disease such as heart disease, various cancers and type 2 diabetes ${ }^{(19-24)}$. A link between lower BMI and vegetarianism has also consistently been reported $^{(25-27)}$, as well as an overall decline in mortality $^{(28)}$. Even though the health effects of vegetarianism and veganism are largely acknowledged, some uncertainties remain ${ }^{(29,30)}$, especially with regard to sufficient vitamin $B_{12}$ and vitamin $D$ concentrations in the diet ${ }^{(31,32)}$.

The present paper investigates the prevalence and sociodemographic variables of self-identified vegetarians, and of LOV, PLOV and self-identified omnivores who consume vegetarian meals. The assumption in this research is that lay persons' definitions of a vegetarian diet differ from expert definitions and information is needed regarding which sociodemographic group's definition differs most from the scientific definition. This is important in order to target health promotion and health policies correctly to different groups. The aim of the research was to promote understanding of the limitations involved in using selfidentification as a basis for estimating health effects in larger populations, especially since vegetarianism is expected to increase in the future. The last part of the paper concentrates on reviewing the intake of selected food types and their nutritional value in different vegetarian groups.

\section{Subjects and method}

\section{Subjects}

The data for the current study were drawn from three sources: the National FINRISK 1997 and 2002 studies and the Health 2000 Health Examination Survey. National FINRISK is a population-based risk factor survey, which has been carried out every five years since 1972 in Finland. The National FINRISK surveys utilize stratified random samples drawn from five areas in Finland: Helsinki and Vantaa (the metropolitan area), the cities of Turku and Loimaa as well as some rural communities in Loimaa, and the provinces of North Karelia, North Savo and Oulu. The study protocol includes health examinations and health questionnaires ${ }^{(14)}$. The 1997 study sample comprised 11000 persons aged 25-74 years, of whom 7159 (65\%) participated in the study ${ }^{(14)}$. A further random sample of 1500 persons aged 65-74 years in two administrative areas in Finland was also included, and 1288 (86\%) of them participated in the study. The FINRISK 2002 sample comprised 13437 persons, of whom 9580 (71\%) participated in the health examination or at least returned the questionnaire ${ }^{(15)}$.
The nationwide Health 2000 Health Examination Survey (Health 2000) was carried out in Finland in 2000-2001 in eighty regions, incorporating fifteen of the bigger cities ${ }^{(33)}$. The study comprised many questionnaires, an extensive interview and a comprehensive health examination including laboratory and functional capacity tests as well as a thorough clinical examination ${ }^{(34)}$. The sample of persons aged 30 years or over comprised 8028 individuals, of whom 6986 (87\%) were interviewed in their home or in an institution. Overall, $84 \%$ participated either in the health examination or in the examination at home. The sample of 18-29-year-olds comprised 1900 individuals, of whom $1503(79 \%)$ participated in the health interview and 1282 returned the health questionnaire given at the interview ${ }^{(35)}$. An FFQ was given at the end of the examination or the interview, and the participants were asked to return it by mail. A total of 6787 persons aged 18 years or above participated in the dietary study. After exclusion of those aged over 80 years, data were available for 6366 persons. The data set of the present study, pooled from the three nationwide surveys, comprised 24393 individuals (data available for 24044 individuals) following the exclusion of those who gave invalid data on their self-defined vegetarian status or their dietary habits.

\section{Questionnaires}

In all three surveys, information on the participants' demographic and socio-economic background, including education, family size, marital status and subjective health, was collected during the health interview and in the questionnaires. The level of education was assessed using information on formal schooling and vocational training. Education was categorized as low, moderate or high for the analyses. Those with no vocational training beyond a vocational course or on-the-job training, and who had not taken the matriculation examination, were classified as having a low education. Vocational training was defined as secondary education regardless of the basic education. Moreover, those who had passed the matriculation examination but who had no vocational training beyond a vocational course or on-the-job training were also classified in this moderate group. High education comprised degree studies at higher vocational institutions, polytechnics and universities. Marital status was categorized as married, co-habiting, divorced, widowed and single. The participants were also asked to assess their own health status on a five-category scale ranging from very bad to very good. This subjective health was further categorized as good or rather good, moderate, and bad or rather bad. The National FINRISK 2002 study and the Health 2000 survey also provided data on the potential use of dietary supplements.

Self-defined vegetarian status was defined on the basis of the question 'Do you consider yourself to be a vegetarian?' in the National FINRISK 1997 and 2002 surveys, and on the basis of the vegetarian diet option on the list of special diets in the Health 2000 survey. 
The questionnaires in the National FINRISK surveys included a food-frequency section including forty foods or food items. The six frequency categories ranged from 'never or less than once per month' to 'once or more per day'. The dietary data in Health 2000 were obtained from a self-administered, semi-quantitative FFQ, which included 128 food items selected on the basis of experiences from previous studies to assess the whole diet over the previous 12 months. The nine frequency categories ranged from 'never or rarely' to 'six or more times per day'. The validity of the FFQ was assessed and the data collected appeared to meet the requirements of epidemiological studies ${ }^{(36)}$.

The participants were divided into consumers or nonconsumers of each food on the basis of their responses to the FFQ. Those who reported once per month or more were considered consumers and those who indicated less than once per month or rarely were considered non-consumers. Three commonly used categories of vegetarianism $^{(4-6)}$ were formed on the basis of reported consumption according to the questionnaire as follows: (i) vegans or lacto-vegetarians were defined as persons who ate meat products, eggs or fish less than once per month; (ii) vegans or lacto-ovo-vegetarians (LOV) were defined as persons eating vegetarian food, including dairy products and sometimes eggs, but no meat, poultry or fish; and (iii) vegans or lacto-ovo-vegetarians or pescolacto-Ovo-vegetarians (PLOV) were defined as those eating vegetarian food, and also dairy products and eggs as well as fish, but no meat or poultry.

The dietary data from Health 2000 were used to describe dietary habits according to vegetarian status. Food consumption was converted into g/d by multiplying the frequency of consumption by fixed portion sizes. The ingredients of mixed foods were broken down into their components. The contents of different nutrients in food items were estimated using the Finnish Food Composition Database release 2 (National Public Health Institute, Helsinki, Finland).

\section{Statistical analyses}

Sample characteristics are described in terms of means and standard deviations for continuous variables, and frequencies (percentage) for categorical variables. Prevalence estimates adjusted for age, gender and the year of the study were estimated using a linear model ${ }^{(37)}$. The statistical significance of the differences between prevalences was tested using the likelihood-ratio test based on the model. The SAS/STAT statistical software package version 8.02 (SAS Institute Inc., Cary, NC, USA) was used for the statistical analyses.

\section{Results}

\section{Prevalence}

Of the 24393 respondents (data about self-identified vegetarian status was available for 24044 respondents), $783(3 \cdot 3 \%)$ considered themselves to be vegetarian (Table 1). However the FFQ revealed that, according to the foodstuffs consumed, only 332 participants $(1 \cdot 4 \%)$ in total followed a PLOV or stricter diet, and $104(0.43 \%)$ followed a LOV or stricter diet. The percentage of female vegetarians was more than double the percentage of males in all of the operationalized definition groups. The percentage of males grew in all of these groups between 1997 and 2002, but there were no significant changes among the females. All in all, there were no large differences in the total proportions of vegetarians between the different samplings utilized in the research.

\section{Socio-economic factors related to different groups}

The differences between self-defined vegetarians and those (PLOV and LOV) fitting the operationalized definition are presented in Table 2, which indicates the prevalence of these groups according to personal characteristics. However defined, vegetarians were mainly younger and predominantly women from the southern part of Finland. Vegetarianism was also more prevalent among single, divorced and widowed people. PLOV had a particularly high level of education and they were often also supplement users. No statistically significant differences in subjective health experiences were found among the vegetarians. Differences between the two definitional groups were evident in the large number of self-defined vegetarians in the older (60-79 years) age group. PLOV and

Table 1 The prevalence of vegetarianism in three nationwide surveys in Finland

\begin{tabular}{|c|c|c|c|c|c|c|c|c|c|c|c|c|}
\hline \multirow[b]{3}{*}{ Type of vegetarian diet } & \multicolumn{12}{|c|}{ Prevalence (\%) } \\
\hline & \multicolumn{3}{|c|}{ FINRISK 1997 (n 8447) } & \multicolumn{3}{|c|}{ Health $2000(n$ 6366) } & \multicolumn{3}{|c|}{ FINRISK 2002 ( $n$ 9580) } & \multicolumn{3}{|c|}{ All (n 24 393) } \\
\hline & Men & Women & Total & Men & Women & Total & Men & Women & Total & Men & Womer & רotal \\
\hline Vegan or lacto-vegetarian* $(n$ 44) & 0.05 & $0 \cdot 22$ & $0 \cdot 13$ & 0.07 & $0 \cdot 28$ & $0 \cdot 19$ & $0 \cdot 16$ & $0 \cdot 28$ & $0 \cdot 22$ & $0 \cdot 10$ & $0 \cdot 26$ & $0 \cdot 18$ \\
\hline Vegan or lacto-ovo-vegetariant $(n$ 104) & 0.09 & $0 \cdot 67$ & $0 \cdot 38$ & $0 \cdot 18$ & $0 \cdot 71$ & 0.47 & $0 \cdot 27$ & 0.59 & $0 \cdot 44$ & $0 \cdot 18$ & 0.65 & 0.43 \\
\hline $\begin{array}{l}\text { Vegan or lacto-ovo-vegetarian or pesco- } \\
\text { lacto-ovo-vegetarian } ¥(n 332)\end{array}$ & 0.59 & $2 \cdot 04$ & $1 \cdot 31$ & 0.63 & 1.99 & $1 \cdot 38$ & $0 \cdot 72$ & $2 \cdot 01$ & $1 \cdot 40$ & 0.65 & $2 \cdot 01$ & $1 \cdot 37$ \\
\hline Self-defined vegetarian $\$(n 783)$ & $3 \cdot 79$ & $4 \cdot 45$ & $4 \cdot 12$ & $1 \cdot 33$ & $2 \cdot 74$ & $2 \cdot 13$ & $2 \cdot 11$ & $4 \cdot 26$ & $3 \cdot 27$ & $2 \cdot 54$ & $3 \cdot 90$ & $3 \cdot 26$ \\
\hline
\end{tabular}

*Meat products, eggs or fish less than once per month.

tMeat products and fish less than once per month.

¥Meat products less than once per month.

$\S$ Data available for 24044 persons. 
Table 2 Multivariate adjusted* prevalence of vegetarianism, self-defined and operationalized from the FFQ, according to personal characteristics: combined data from three nationwide surveys in Finland ( $n$ 24 393)

\begin{tabular}{|c|c|c|c|}
\hline & $\begin{array}{l}\text { Self-defined vegetarian } \\
\qquad(n 783)\end{array}$ & $\begin{array}{l}\text { Pesco-lacto-ovo-vegetarian } \\
\text { according to FFQ ( } n \text { 228) }\end{array}$ & $\begin{array}{l}\text { Vegetariant according } \\
\text { to FFQ }(n 104)\end{array}$ \\
\hline \multicolumn{4}{|l|}{ Gender $\ddagger$} \\
\hline Men & $2 \cdot 46$ & 0.48 & $0 \cdot 20$ \\
\hline Women & 3.98 & $1 \cdot 35$ & 0.64 \\
\hline $\begin{array}{l}P \text { value for } \\
\text { heterogeneity }\end{array}$ & $<0.001$ & $<0.001$ & $<0.001$ \\
\hline \multicolumn{4}{|l|}{ Age (years)§ } \\
\hline $18-29$ & $3 \cdot 56$ & $1 \cdot 85$ & $1 \cdot 46$ \\
\hline $30-59$ & 2.53 & 0.88 & 0.34 \\
\hline $60-79$ & $5 \cdot 20$ & 0.71 & 0.23 \\
\hline $\begin{array}{l}P \text { value for } \\
\text { heterogeneity }\end{array}$ & $<0.001$ & $<0.001$ & $<0.001$ \\
\hline \multicolumn{4}{|l|}{ Area } \\
\hline South & 3.58 & $1 \cdot 40$ & 0.68 \\
\hline West & $3 \cdot 17$ & 1.00 & 0.69 \\
\hline Middle & $2 \cdot 81$ & 0.87 & 0.27 \\
\hline East & 3.37 & 0.88 & 0.27 \\
\hline North & $2 \cdot 71$ & 0.48 & 0.25 \\
\hline $\begin{array}{l}P \text { value for } \\
\text { heterogeneity }\end{array}$ & $0 \cdot 15$ & $<0.001$ & $<0.001$ \\
\hline \multicolumn{4}{|l|}{ Education } \\
\hline Low & $3 \cdot 64$ & 0.58 & $0 \cdot 22$ \\
\hline Moderate & $2 \cdot 74$ & 0.74 & 0.36 \\
\hline High & $3 \cdot 80$ & 1.99 & 0.66 \\
\hline $\begin{array}{l}P \text { value for } \\
\text { heterogeneity }\end{array}$ & $<0.001$ & $<0.001$ & $<0.001$ \\
\hline \multicolumn{4}{|l|}{ Marital status } \\
\hline Single & $4 \cdot 67$ & $1 \cdot 87$ & 0.84 \\
\hline Co-habiting & 3.39 & $1 \cdot 19$ & 0.50 \\
\hline Married & $2 \cdot 57$ & 0.51 & 0.23 \\
\hline Divorced & $4 \cdot 19$ & $1 \cdot 38$ & 0.61 \\
\hline Widowed & $5 \cdot 13$ & $1 \cdot 80$ & 0.97 \\
\hline $\begin{array}{l}P \text { value for } \\
\text { heterogeneity }\end{array}$ & $<0.001$ & $<0.001$ & $<0.001$ \\
\hline \multicolumn{4}{|l|}{ Family size } \\
\hline 1 person & $4 \cdot 86$ & 1.96 & 0.89 \\
\hline 2 persons & $3 \cdot 62$ & 1.02 & 0.48 \\
\hline 3 or more persons & 2.09 & 0.36 & $0 \cdot 11$ \\
\hline $\begin{array}{l}P \text { value for } \\
\text { heterogeneity }\end{array}$ & $<0.001$ & $<0.001$ & $<0.001$ \\
\hline \multicolumn{4}{|l|}{ Subjective health } \\
\hline $\begin{array}{l}\text { Good or rather } \\
\text { good }\end{array}$ & $3 \cdot 04$ & $1 \cdot 11$ & 0.46 \\
\hline Moderate & $3 \cdot 18$ & 0.63 & 0.32 \\
\hline Bad or rather bad & $4 \cdot 50$ & 0.83 & 0.51 \\
\hline $\begin{array}{l}P \text { value for } \\
\text { heterogeneity }\end{array}$ & 0.003 & 0.003 & $0 \cdot 24$ \\
\hline \multicolumn{4}{|l|}{ Supplement userll } \\
\hline No & $2 \cdot 19$ & 0.55 & 0.29 \\
\hline Yes & $3 \cdot 47$ & $1 \cdot 46$ & 0.64 \\
\hline $\begin{array}{l}P \text { value for } \\
\text { heterogeneity }\end{array}$ & $<0.001$ & $<0.001$ & 0.002 \\
\hline
\end{tabular}

${ }^{*}$ Adjusted for age, gender and year of the study. +Vegan or lacto-ovo-vegetarian.

$\ddagger$ Not adjusted for gender.

$\S$ Not adjusted for age.

IIData not available in FINRISK 1997 (available for 15045 persons).

LOV prevalence increased with level of education, but self-identified vegetarianism was also high among the less educated.

The personal characteristics of those of vegetarian status according to the operationalized definition are presented in Table 3. A very large proportion of PLOV and LOV in the present study were women $(75.6$ and $78 \cdot 1 \%$, respectively) compared with omnivores $(52 \cdot 2 \%)$, they were younger and a considerable number of them had the highest educational level. They also considered their health to be good, and were often supplement users. The two groups were quite similar in characteristics except that PLOV had higher educational levels $(37 \cdot 6 \%$ belonged to the highest group).

The majority $(80 \cdot 0 \%)$ of the self-defined vegetarians were omnivores according to the operationalized definition 
Table 3 Multivariate adjusted ${ }^{\star}$ distribution of personal characteristics according to operationalized vegetarian status from the FFQ: combined data from three nationwide surveys in Finland ( $n$ 24 393)

\begin{tabular}{|c|c|c|c|c|}
\hline & $\begin{array}{l}\text { Omnivore } \\
(n \text { 23 971) }\end{array}$ & $\begin{array}{l}\text { Pesco-lacto-ovo-vegetarian } \\
\text { according to FFQ ( } n \text { 228) }\end{array}$ & $\begin{array}{l}\text { Lacto-ovo-vegetariant } \\
\text { according to FFQ ( } n \text { 104) }\end{array}$ & $P$ value \\
\hline Gender, \% men $\ddagger$ & $47 \cdot 8$ & $24 \cdot 4$ & $21 \cdot 9$ & $<0.001$ \\
\hline Age (years), mean (SD)§ & $48 \cdot 1(13 \cdot 8)$ & $44 \cdot 7(14 \cdot 0)$ & $40 \cdot 3(14 \cdot 6)$ & $<0.001$ \\
\hline Area, \% south & 24.9 & $36 \cdot 4$ & 38.9 & $<0.001$ \\
\hline Education, \% high & $17 \cdot 6$ & $37 \cdot 6$ & $31 \cdot 3$ & $<0.001$ \\
\hline Marital status, $\%$ married & $58 \cdot 1$ & $32 \cdot 3$ & $31 \cdot 8$ & $<0.001$ \\
\hline Family size, \% single & $19 \cdot 7$ & $41 \cdot 3$ & $42 \cdot 4$ & $<0.001$ \\
\hline Subjective health, good or rather good & $59 \cdot 4$ & $69 \cdot 5$ & $64 \cdot 9$ & 0.002 \\
\hline Supplement user, \%ll & $44 \cdot 0$ & $66 \cdot 3$ & $62 \cdot 4$ & $<0.001$ \\
\hline
\end{tabular}

*Adjusted for age, gender and year of the study.

tVegan or lacto-ovo-vegetarian.

$\ddagger$ Not adjusted for gender.

$\S$ Not adjusted for age.

IIData not available in FINRISK 1997 (available for 15045 persons).

Table 4 Distribution* of personal characteristics according to self-defined vegetarian status: combined data from three nationwide surveys in Finland ( $n$ 24 393)

\begin{tabular}{|c|c|c|c|c|c|c|}
\hline & \multicolumn{3}{|c|}{ Self-defined vegetarian ( $n$ 691) } & \multicolumn{3}{|c|}{ Self-defined omnivore ( $n$ 23231) } \\
\hline & $\begin{array}{l}\text { Omnivore } \\
\text { (n 554) }\end{array}$ & $\begin{array}{l}\text { Pesco-lacto-ovo- } \\
\text { vegetariant }(n \text { 137) }\end{array}$ & $P$ value & $\begin{array}{l}\text { Omnivoret } \\
(\text { n 23 142) }\end{array}$ & $\begin{array}{l}\text { Pesco-lacto-ovo- } \\
\text { vegetariant ( } n \text { 89) }\end{array}$ & $P$ value \\
\hline Gender, \% men $\ddagger$ & $45 \cdot 4$ & $17 \cdot 9$ & $<0.001$ & $47 \cdot 8$ & $41 \cdot 3$ & $0 \cdot 22$ \\
\hline Age (years), mean (SD)§ & $56 \cdot 0(12.9)$ & $44 \cdot 2(13 \cdot 2)$ & $<0.001$ & $47 \cdot 8(13 \cdot 7)$ & $45 \cdot 7(15 \cdot 0)$ & $0 \cdot 15$ \\
\hline Area, \% south & $24 \cdot 5$ & $34 \cdot 1$ & 0.02 & $25 \cdot 0$ & $33 \cdot 0$ & 0.08 \\
\hline Education, \% high & $10 \cdot 8$ & 33.9 & $<0.001$ & $18 \cdot 0$ & $38 \cdot 2$ & $<0.001$ \\
\hline Marital status, \% married & $54 \cdot 6$ & $38 \cdot 9$ & 0.002 & $58 \cdot 3$ & $29 \cdot 2$ & $<0.001$ \\
\hline Family size, $\%$ single & $26 \cdot 6$ & $41 \cdot 4$ & 0.002 & $19 \cdot 5$ & $40 \cdot 7$ & $<0.001$ \\
\hline $\begin{array}{l}\text { Subjective health, \% good } \\
\text { or rather good }\end{array}$ & $43 \cdot 9$ & $65 \cdot 4$ & $<0.001$ & $60 \cdot 0$ & $65 \cdot 6$ & 0.25 \\
\hline Supplement user, \%ll & $52 \cdot 6$ & $75 \cdot 5$ & $<0.001$ & $43 \cdot 9$ & $63 \cdot 6$ & 0.001 \\
\hline
\end{tabular}

${ }^{*}$ Adjusted for age, gender and year of the study.

†According to FFQ.

¥Not adjusted for gender.

$\S$ Not adjusted for age.

IIData not available in FINRISK 1997 (available for 15045 persons).

(Table 4). According to the FFQ responses, these so-called vegetarians differed from PLOV in age (they were older) and gender distribution (which was much closer to that of the general population). There were also fewer people who felt that their subjective health was good or rather good in this group than in any other group in the study. People who considered themselves omnivores but followed a PLOV diet had a high level of education and were predominantly single. Among the self-defined vegetarians those who followed a vegetarian diet, according to the FFQ, were more likely to be supplement users $(75 \cdot 5 \%)$ than those in the omnivore group (52.6\%).

\section{Food intakes}

The mean daily intakes of selected food items and nutrients adjusted for age, gender and energy intake are presented in Table 5. PLOV consumed higher amounts of grains and especially rye than subjects in the other groups. They also ate more vegetables $(429 \mathrm{~g} / \mathrm{d})$ than the omnivores $(276 \mathrm{~g} / \mathrm{d})$. They did not consume larger amounts of milk products than those in the other groups, but they did consume more cheese. They also consumed more fish. PLOV consumed some meat and meat products. An analysis of the crude numbers (data not displayed) showed that their unadjusted consumption of meat was $13.9 \mathrm{~g} / \mathrm{d}$ and their consumption of poultry $1 \cdot 0 \mathrm{~g} / \mathrm{d}$. There were no significant differences between the groups in the consumption of fat, butter and confectionery products. The self-defined vegetarians differed from the omnivores in their higher vegetable $(409 \mathrm{~g} / \mathrm{d})$ and lower meat $(103 \mathrm{~g} / \mathrm{d})$ consumption. Despite their perception of themselves as vegetarians, they included a considerable amount of meat in their diet. Among selfdefined vegetarians the unadjusted consumption of meat and meat products was $88.9 \mathrm{~g} / \mathrm{d}$.

\section{Nutrient intakes}

There were no significant differences between PLOV and omnivores in the intake of nutrients. The former consumed less energy and their fibre intake was higher. There were differences in energy sources between the self-defined vegetarians and the omnivores: the distribution 
Table 5 Mean daily intakes* (and standard deviations) of selected food items and nutrients in Finnish vegetarians and omnivores, according to the operationalized definition and self-definition in the Health 2000 survey

\begin{tabular}{|c|c|c|c|c|c|c|c|c|c|c|}
\hline & \multicolumn{2}{|c|}{$\begin{array}{l}\text { Omnivoret } \\
(n \text { 6277) }\end{array}$} & \multicolumn{2}{|c|}{$\begin{array}{l}\text { Pesco-lacto-ovo- } \\
\text { vegetariant }(n 58)\end{array}$} & \multirow[b]{2}{*}{$P$ value } & \multicolumn{2}{|c|}{$\begin{array}{l}\text { Self-defined } \\
\text { omnivore } \\
(n \text { 6228) }\end{array}$} & \multicolumn{2}{|c|}{$\begin{array}{l}\text { Self-defined } \\
\text { vegetarian } \\
(n 134)\end{array}$} & \multirow[b]{2}{*}{$P$ value } \\
\hline & Mean & SD & Mean & SD & & Mean & SD & Mean & SD & \\
\hline \multicolumn{11}{|l|}{ Foodstuff (g) } \\
\hline Grains & $189 \cdot 3$ & $84 \cdot 2$ & $221 \cdot 0$ & $83 \cdot 2$ & $<0.001$ & 189 & 84 & 203 & 95 & 0.005 \\
\hline Rye and hard bread & $54 \cdot 1$ & $36 \cdot 7$ & $71 \cdot 7$ & $38 \cdot 2$ & $<0.001$ & $54 \cdot 1$ & $36 \cdot 8$ & $59 \cdot 4$ & $39 \cdot 6$ & 0.08 \\
\hline Vegetables & 276 & 194 & 429 & 275 & $<0.001$ & 275 & 192 & 409 & 318 & $<0.001$ \\
\hline Potatoes & 175 & 124 & 154 & 101 & $0 \cdot 15$ & 175 & 124 & 160 & 142 & $0 \cdot 13$ \\
\hline Fruit, berries and juice & 297 & 256 & 355 & 266 & 0.06 & 297 & 255 & 350 & 288 & 0.01 \\
\hline Milk and milk products & 592 & 368 & 575 & 340 & 0.03 & 590 & 367 & 598 & 420 & $0 \cdot 79$ \\
\hline Cheese & $42 \cdot 9$ & $37 \cdot 2$ & $63 \cdot 2$ & $54 \cdot 8$ & $<0.001$ & $43 \cdot 0$ & $37 \cdot 1$ & $47 \cdot 8$ & $54 \cdot 0$ & $0 \cdot 11$ \\
\hline Eggs & $27 \cdot 8$ & $24 \cdot 8$ & $28 \cdot 8$ & $14 \cdot 5$ & 0.71 & $27 \cdot 7$ & $24 \cdot 6$ & $29 \cdot 7$ & $31 \cdot 3$ & 0.28 \\
\hline Fish & $45 \cdot 7$ & $39 \cdot 9$ & $65 \cdot 1$ & $51 \cdot 6$ & $<0.001$ & $45 \cdot 7$ & $39 \cdot 2$ & $47 \cdot 4$ & $72 \cdot 0$ & 0.58 \\
\hline Meat and meat products & 176 & 100 & 43 & 13 & $<0.001$ & 175 & 100 & 103 & 131 & $<0.001$ \\
\hline Red meat & $145 \cdot 0$ & $88 \cdot 4$ & $42 \cdot 1$ & $12 \cdot 0$ & $<0.001$ & $144 \cdot 0$ & $87 \cdot 8$ & $90 \cdot 4$ & $120 \cdot 0$ & $<0.001$ \\
\hline Poultry & $30 \cdot 9$ & $38 \cdot 8$ & 0.9 & $1 \cdot 1$ & $<0.001$ & $30 \cdot 9$ & $38 \cdot 9$ & $13 \cdot 0$ & $24 \cdot 8$ & $<0.001$ \\
\hline Fat & $48 \cdot 1$ & $24 \cdot 4$ & $48 \cdot 1$ & $25 \cdot 6$ & 0.98 & $48 \cdot 0$ & $24 \cdot 2$ & $49 \cdot 1$ & $36 \cdot 5$ & 0.43 \\
\hline Butter and butter spread & $11 \cdot 0$ & 8.9 & $11 \cdot 6$ & $7 \cdot 7$ & 0.55 & $11 \cdot 0$ & 8.9 & $10 \cdot 8$ & $8 \cdot 6$ & 0.75 \\
\hline Sweets and chocolate & $17 \cdot 4$ & $21 \cdot 7$ & $22 \cdot 1$ & $34 \cdot 5$ & 0.08 & $17 \cdot 5$ & $21 \cdot 8$ & $20 \cdot 7$ & $28 \cdot 3$ & 0.06 \\
\hline \multicolumn{11}{|l|}{ Nutrients } \\
\hline Energy (kJ) & 9659 & 3542 & 8252 & 3697 & 0.03 & 9646 & 3605 & 9144 & 5007 & $0 \cdot 11$ \\
\hline Energy (kcal) & 2307 & 846 & 1971 & 883 & 0.03 & 2304 & 861 & 2184 & 1196 & $0 \cdot 11$ \\
\hline Carbohydrates (\% of energy) & 44.9 & $5 \cdot 8$ & $50 \cdot 4$ & $5 \cdot 0$ & $<0.001$ & 44.9 & $5 \cdot 8$ & $49 \cdot 5$ & $6 \cdot 7$ & $<0.001$ \\
\hline Protein (\% of energy) & $17 \cdot 2$ & $2 \cdot 2$ & $15 \cdot 2$ & $2 \cdot 5$ & $<0.001$ & $17 \cdot 2$ & $2 \cdot 3$ & $15 \cdot 5$ & $2 \cdot 8$ & $<0.001$ \\
\hline Fat (\% of energy) & $36 \cdot 2$ & $4 \cdot 9$ & $32 \cdot 7$ & $4 \cdot 7$ & $<0.001$ & $36 \cdot 2$ & $4 \cdot 9$ & $33 \cdot 5$ & $6 \cdot 0$ & $<0.001$ \\
\hline SFA (\% of energy) & $14 \cdot 7$ & $2 \cdot 5$ & $13 \cdot 3$ & $2 \cdot 9$ & $<0.001$ & $14 \cdot 7$ & $2 \cdot 5$ & $13 \cdot 5$ & $3 \cdot 0$ & $<0.001$ \\
\hline MUFA (\% of energy) & $12 \cdot 3$ & 1.9 & $10 \cdot 5$ & $1 \cdot 5$ & $<0.001$ & $12 \cdot 3$ & $1 \cdot 9$ & $11 \cdot 0$ & $2 \cdot 3$ & $<0.001$ \\
\hline PUFA ( $\%$ of energy) & $5 \cdot 7$ & $1 \cdot 2$ & $5 \cdot 8$ & $1 \cdot 1$ & 0.67 & $5 \cdot 7$ & $1 \cdot 2$ & $5 \cdot 7$ & $1 \cdot 6$ & 0.89 \\
\hline Fibre $(\mathrm{g})$ & $24 \cdot 5$ & $10 \cdot 7$ & $33 \cdot 2$ & $14 \cdot 2$ & $<0.001$ & $24 \cdot 5$ & $10 \cdot 7$ & $29 \cdot 6$ & $14 \cdot 2$ & $<0.001$ \\
\hline $\mathrm{Ca}(\mathrm{mg})$ & 1343 & 605 & 1435 & 643 & 0.08 & 1342 & 601 & 1389 & 791 & $0 \cdot 18$ \\
\hline $\mathrm{Fe}(\mathrm{mg})$ & $15 \cdot 4$ & $6 \cdot 0$ & $16 \cdot 2$ & $5 \cdot 8$ & 0.03 & $15 \cdot 4$ & $6 \cdot 0$ & $16 \cdot 0$ & $7 \cdot 9$ & 0.01 \\
\hline Vitamin $B_{12}(\mu \mathrm{g})$ & $9 \cdot 9$ & $5 \cdot 7$ & $8 \cdot 0$ & $4 \cdot 2$ & $<0.001$ & $9 \cdot 9$ & $5 \cdot 7$ & $8 \cdot 5$ & $7 \cdot 9$ & $<0.001$ \\
\hline Vitamin D $(\mu \mathrm{g})$ & $6 \cdot 7$ & $4 \cdot 5$ & $7 \cdot 7$ & $5 \cdot 4$ & 0.03 & $6 \cdot 7$ & $4 \cdot 4$ & 6.7 & $7 \cdot 0$ & 0.81 \\
\hline
\end{tabular}

${ }^{*}$ Adjusted for age, gender and energy intake.

tAccording to the FFQ.

(carbohydrates-proteins-fats) of energy intake was 45:17:36 for the latter and 50:16:34 for the former. Both selfidentified vegetarians and PLOV obtained more energy from carbohydrates and less from fat. The intake SFA and MUFA was smaller among PLOV and self-defined vegetarians than among omnivores, but there were no differences in PUFA intake. Fibre intake was higher among PLOV and self-defined vegetarians, but there were no significant differences between the groups in the intake of $\mathrm{Ca}$ and $\mathrm{Fe}$. Vitamin $\mathrm{B}_{12}$ intake was smaller among the self-identified vegetarians $(8.5 \mu \mathrm{g} / \mathrm{d})$ and PLOV $(8.0 \mu \mathrm{g} / \mathrm{d})$ than among the omnivores $(9 \cdot 9 \mu \mathrm{g} / \mathrm{d})$, and there were no significant differences in vitamin $\mathrm{D}$ intake.

\section{Discussion}

The results of the present study reveal a large discrepancy in the number of vegetarians in society depending on whether the calculation is based on self-definition or operationalized definition: in the former case, the proportion of vegetarians in the whole population was $3 \cdot 3 \%$, but only $0.43 \%$ for LOV and $1.4 \%$ for PLOV when the operationalized definition was used. Self-identification seems to give estimates that are double those calculated from the FFQ. This difference can probably be partly explained by the ambiguous interpretation of the term vegetarian. In particular, there were many self-identified vegetarians in the group with lower educational status and in the elderly. One could draw the conclusion that at least some of them confused the question 'Do you follow any special diet - such as a vegetarian diet?' with the question 'Do you include vegetables in your diet?' Another explanatory factor could be that vegetarianism is considered a positive behaviour and people want to relate to it, even though they do not eat only vegetarian food ${ }^{(38)}$.

The discrepancy between the operationalized definition and self-identification decreased slightly between the years of the surveys (1997-2002), which may mean that knowledge about what is meant by a vegetarian way of eating has increased. On the other hand, it cannot be ruled out that this reduction might instead be due to the different ways of asking about vegetarianism used in the surveys and also the fact that persons aged 18-25 years were included in the Health 2000 survey but not in the FINRISK surveys. Previous studies in England have identified vegetarians as 
likely to be female, well educated and living in the southern part of the country ${ }^{(39)}$. The present results suggest that similar characteristics describe Finnish vegetarians in all groups. These differences can be partly explained by the higher rate of urbanization. The higher prevalence of vegetarianism among women has often been explained by the perceived masculinity of meat as a food ${ }^{(40)}$. Single women also have more freedom to choose their diet, which may partly explain the high proportion of single people among vegetarians. Vegetarians (PLOV and LOV) were also characterized by good subjective health and supplement usage. However, some people who followed a PLOV or a stricter diet according to the operationalized definition did not consider themselves vegetarian. There may be several explanations for this: they do not see themselves as vegetarians because they eat fish or they consume meat products at very low frequencies, such as when visiting relatives.

An analysis of the mean daily intakes of selected food items showed that PLOV consumed higher amounts of grains, vegetables, fish and cheese than the other groups. There were differences between the self-defined vegetarians and the omnivores in terms of higher vegetable consumption and lower meat consumption among the former. A small amount of meat was observed in the diet of PLOV and self-defined vegetarians apparently resulting from rare consumption or the standard recipe file used to break down the mixed foods.

Energy sources differed between self-defined vegetarians and omnivores, and both the former and PLOV obtained a larger proportion of energy from carbohydrates and a lower proportion from fat. Their fibre intake was also higher than among the other vegetarians. Furthermore, their vitamin $\mathrm{B}_{12}$ intake was lower than that of the total population, but much above the critical level of $2 \mu \mathrm{g} / \mathrm{d}^{(6)}$. There were no significant differences in vitamin $\mathrm{D}$ intake among the groups.

Knowledge of the prevalence of vegetarianism on the national level is currently limited. A large sample was used in the current study in order to produce more reliable estimates. There are some limitations, however. Our data did not include children (0-18 years), which could have lowered the prevalence numbers because vegetarianism is popular among young girls ${ }^{(17)}$. There were also differences between the frequency categories in the samples, and there was no 'never use' category in the consumption frequency questionnaires. Nutritional intake also differs by individual, so there is a danger of generalization when average data are utilized. Adjusting nutrient intakes according to energy intake affected the consumption to some degree and resulted in higher meat consumption among PLOV, for example.

Some studies have used self-definition as a way of examining a vegetarian way of eating ${ }^{(41)}$ and have concluded that self-identified vegetarians follow healthier diets than the general population. The conclusion in the current study is that both PLOV and self-defined vegetarians follow a healthier diet than the general population. In addition, however, it is important to note that $80 \%$ of the self-identified vegetarians did not follow a vegetarian diet according the operationalized definition; in the same sample self-identification gave more than double the incidence of vegetarianism thus defined. This can mean at least three things: (i) that lay persons' definition of vegetarianism differs from the expert definition; (ii) that people do not know what food products they consume; or (iii) that some consumers want to identify themselves as vegetarian even though they consume meat. Related to the first point it would be important for a nutritionist to investigate in depth what a person means by a vegetarian diet before giving any nutritional advice. This is especially important in the case of older and less educated people. Related to the second point it could be useful to have vegetarian and vegan labels on food products, so that consumers would have a better understanding of what they are actually consuming. What is certain, however, is that self-identification is not a good method for observing the prevalence of vegetarianism at national level, and should be used with caution in identifying its health effects in certain groups.

\section{Acknowledgements}

We express our deep appreciation to the participants and staff of the National FINRISK 1997, 2002 and Health 2000 studies. Writing of this paper was funded by Academy of Finland BRIGADE project.

M.V. designed the study, with the help of J.M. J.M., T.H. and S.M. were involved in the acquisition of the data and M.V., J.M. and S.M. carried out the interpretation. J.M. and T.H. conducted the statistical analyses of the FINRISK 1997, 2002 and Health 2000 data. M.V. wrote the manuscript collaboratively with all the co-authors.

The authors declare no conflict of interest.

\section{References}

1. Weinsier RL (2000) Use of the term vegetarian. Am J Clin Nutr 71, 1211-1212.

2. Spencer C (1993) The Heretic's Feast: History of Vegetarianism. London: Fourth Estate \& University Press of New England.

3. Oxford English Dictionary (1989) Oxford: Oxford University Press.

4. Maurer D (2002) Vegetarianism: Movement or Moment? Philadelphia, PA: Temple University Press.

5. Sabate J, Ratzin-Turner R \& Brown J (2001) Vegetarian diets: description and trends. In Vegetarian Nutrition, pp. 3-18 [J Sabate, editor]. Boca Raton, FL: CRC Press.

6. Phillips F (2005) Vegetarian nutrition. Nutr Bull 30, 132-167.

7. White R \& Frank E (1994) Health effects and prevalence of vegetarianism. West J Med 160, 465-471.

8. Larsson CL, Klock KS, Åstrøm AN, Haugejorden O \& Johansson G (2001) Food habits of young Swedish and Norwegian vegetarians and omnivores. Public Health Nutr 4, 1005-1014. 
9. Key TJ, Appleby PN \& Rosell MS (2006) Health effects of vegetarian and vegan diets. Proc Nutr Soc 65, 35-41.

10. Food Standards Agency (2004) Consumer Attitudes to Food Standards Wave 4. UK Report prepared for the Food Standards Agency and COI Communications. COI Ref. 257960. London: TNS.

11. The Vegetarian Society (not dated) Statistics Information Sheet. http://www.vegsoc.org/info/statveg.html (accessed April 2007).

12. Henderson L, Gregory J \& Swan G (2002) National Diet and Nutrition Survey: Adults Aged 19-64 Years. vol. 1: Types and Quantities of Foods Consumed. London: The Stationery Office.

13. Dietz T, Stirling F, Kalof L, Stern P \& Guagnano G (1995) Values and vegetarianism: an exploratory analysis. Rural Sociol 60, 533-542.

14. Vartiainen E, Jousilahti P, Juolevi A, Sundvall J, Alfthan G, Salminen I \& Puska P (1998) FINRISKI 1997. Tutkimus kroonisten kansantautien riskitekijöistä, niihin liittyvistä elintavoista, oireista ja terveyspalvelujen käytöstä (FINRISKI 1997. A National Study of Risk Factors of Chronic Diseases, Life-Style, Symptoms and Use of Health Care Services). Publications of the National Public Health Institute no. B1/1998. Helsinki: National Public Health Institute.

15. Laatikainen $T$, Tapanainen H, Alftan G, Salminen I, Sundvall J, Leiviskä J, Harald K, Jousilahti P, Salomaa V \& Vartiainen E (2003) FINRISKI 2002. Tutkimus kroonisten kansantautien riskitekijöistä, niibin liittyvistä elintavoista, oireista, psykososiaalisista tekijöistä ja terveyspalvelujen käytöstä. Tutkimuksen toteutus ja tulokset 2 (FINRISKI 2002. A National Study of Risk Factors of Chronic Diseases, Life-Style, Symptoms, Psychosocial Factors and Use of Health Care Services. Survey Implementation and Results 2). Publications of the National Public Health Institute no. B7/2003. Helsinki: National Public Health Institute.

16. Eurobarometer (2005) Attitudes of Consumers Towards the Welfare of Farmed Animals, Special Eurobarometer 229/Wave 63.2 - TNS Opinion \& Social. Brussels: European Commission, Directorate General Press and Communication.

17. Kosonen H, Rimpelä A, Rauma AL, Väisänen P, Pere L, Virtanen SM \& Rimpelä M (2005) Consumption of special diet among Finnish adolescents in 1979-2001: repeated national cross-sectional surveys. Soz Praventivmed 50, 142-150.

18. Vinnari MV (2007) The future of meat consumption expert views from Finland. Technol Forecast Soc Change doi:10.1016/j.techfore.2007.02.001

19. Key TK \& Appleby PN (2001) Vegetarianism, coronary risk factors and coronary heart disease. In Vegetarian Nutrition, pp. 33-55 [J Sabate, editor]. Boca Raton, FL: CRC Press.

20. Potter JD (2000) Your mother was right: eat your vegetables. Asia Pac J Clin Nutr 9, 10-12.

21. Bazzano LA, He J, Ogden LG, Loria CM, Vupputuri S, Myers L \& Whelton PK (2002) Fruit and vegetable intake and risk of cardiovascular disease in US adults: the first National Health and Nutrition Examination Survey Epidemiologic Follow-up Study. Am J Clin Nutr 76, 93-99.

22. American Dietetic Association (2003) Position of the American Dietetic Association and Dietitians of Canada: vegetarian diets. J Am Diet Assoc 103, 748-765.

23. Key TJ, Appleby PN, Davey GK, Allen NE, Spencer EA \& Travis RC (2003) Mortality in British vegetarians: review and preliminary results from EPIC-Oxford. Am J Clin Nutr $\mathbf{7 8}, 533-538$.

24. Montonen J, Knekt P, Järvinen R, Aromaa A \& Reunanen A (2003) Whole-grain and fiber intake and the incidence of type 2 diabetes. Am J Clin Nutr 77, 622-629.
25. Key TJ, Fraser GE, Thorogood M et al. (1999) Mortality in vegetarians and nonvegetarians: detailed findings from a collaborative analysis of 5 prospective studies. Am J Clin Nutr 70, 3 Suppl., S516-S524.

26. Spencer EA, Appleby PN, Davey GK \& Key TJ (2003) Diet and body mass index in 38000 EPIC-Oxford meat-eaters, fish-eaters, vegetarians and vegans. Int J Obes Relat Metab Disord 27, 728-734.

27. Newby PK, Tucker KL \& Wolk A (2005) Risk of overweight and obesity among semivegetarian, lactovegetarian, and vegan women. Am J Clin Nutr 81, 1267-1274.

28. Key TJ, Thorogood M, Burr ML, Mann J \& Appleby PN (2002) Mortality in British vegetarians. Public Health Nutr $\mathbf{5}, 29-36$.

29. Fraser GE (1999) Associations between diet and cancer, ischemic heart disease, and all-cause mortality in nonHispanic white California Seventh-day Adventists. Am J Clin Nutr 70, 3 Suppl., S532-S538.

30. Willett W (2003) Lessons from dietary studies in Adventists and questions for the future. Am J Clin Nutr 78, 539-543.

31. Herrmann W, Schorr H, Obeid R \& Geisel J (2003) Vitamin B-12 status, particularly holotranscobalamin II and methylmalonic acid concentrations, and hyperhomocysteinemia in vegetarians. Am J Clin Nutr 78, 131-136.

32. Parsons TJ, van Dusseldorp $M$, van der Vliet $M$, van de Werken K, Schaafsma G \& van Staveren WA (1997) Reduced bone mass in Dutch adolescents fed a macrobiotic diet in early life. J Bone Miner Res 12, 1486-1494.

33. Heistaro S (editor) (2005) Menetelmäraportti: Terveys 2000 -tutkimuksen toteutus, aineisto ja menetelmät (Method Report. Implementation and Methods of the Health 2000 Survey). Publications of the National Public Health Institute no. B6/2005. Helsinki: National Public Health Institute.

34. Aromaa A \& Koskinen S (editors) (2004) Terveys ja toimintakyky Suomessa, Terveys 2000 -tutkimuksen perustulokset (Health and Functional Capacity in Finland. Baseline Results of the Health 2000 Health Examination Survey). Publications of the National Public Health Institute no. B12/2004. Helsinki: National Public Health Institute.

35. Koskinen S, Kestilä L, Martelin T \& Aromaa A (editors) (2004) Nuorten aikuisten terveys. Terveys 2000 -tutkimuksen perustulokset 1829-vuotiaiden terveydestä ja siihen liittyvistä tekijöistä (The Health of Young Adults. Baseline Results of the Health 2000 Study on the Health of 18 to 29-year-olds and the Factors Associated With It). Publications of the National Public Health Institute no. B12/2004. Helsinki: National Public Health Institute.

36. Paalanen L, Männistö S, Virtanen MJ, Knekt P, Räsänen L, Montonen J \& Pietinen P (2006) Validity of a food frequency questionnaire varied by age and body mass index. J Clin Epidemiol 59, 994-1001.

37. Cohen J \& Cohen P (1975) Applied Multiple Regression/ Correlation Analysis for the Behavioral Sciences. Hillsdale, NJ: Erlbaum.

38. Povey R, Wellens B \& Conner M (2000) Attitudes towards following meat, vegetarian and vegan diets: an examination of the role of ambivalence. Appetite 37, 15-26.

39. Keane A \& Willets A (1996) Concepts of Healthy Eating: An Anthropological Investigation in South-East London. London: Goldsmiths College.

40. Twigg J (1983) Vegetarianism and the meanings of meat. In The Sociology of Food and Eating: Essays on the Sociological Significance of Food, pp. 18-30 [A Murcott, editor]. Aldershot, UK: Gover.

41. Haddad EH \& Tanzman JS (2003) What do vegetarians in the United States eat? Am J Clin Nutr 78, 626-632. 